\title{
The interrelationships between relationship marketing constructs and customer engagement dimensions
}

\author{
䏍系营销结构与顾客参与维度之间的相互矣系 \\ Estelle van Tonder ${ }^{\mathrm{a}}$ and Daniël Johannes Petzer ${ }^{\mathrm{b}}$ \\ ${ }^{a}$ School of Management Sciences, North-West University, Potchefstroom, South Africa; \\ ${ }^{\mathrm{b}}$ Gordon Institute of Business Science, University of Pretoria, Sandton, South Africa
}

The study examines the interrelationships between selected relationship marketing constructs, namely customer satisfaction, trust, perceived value and commitment, and their effect on the dimensions underlying customer engagement. The study is quantitative and an explanatory research design was followed. A total of 489 selfadministered questionnaires were collected from customers of short-term insurance providers on the basis of convenience. Customer satisfaction impacts positively on affective commitment and trust. Customer value also impacts positively on affective commitment and trust, while trust impacts positively on affective commitment. Affective commitment in turn impacts positively on the four customer engagement dimensions: interaction, attention, absorption and affection. The research findings offer an initial understanding of the interrelationships between key relationship marketing constructs and their ultimate effect on various customer engagement dimensions. These matters have received little attention in marketing research, and knowledge of the proposed relationships may lead to further research on this topic.

本研究考察了选定的关系营销结构之间的相互关系, 即顾客满意度, 信任度, 感知价 值和承诺, 以及它们对顾客参与度的影响。这项研究是定量的, 并遵循解释性研究设 计。在方便的基础上, 从短期保险供应商的顾客那里收集了489份自填式问卷。顾客满 意度对情感承诺和信任产生积极影响。顾客价值也对情感承诺和信任产生正向影响, 而信任对情感承诺产生积极影响。反过来, 情感承诺会对四个顾客参与维度产生积极 影响: 互动, 䏌注, 吸收和情感。研究结果初步了解了全键营销结构之间的相互全 系, 以及它们对各种顾客参与维度的最终影响。这些问题在营销研究中很少受到余 注, 而且全于提出的全系的知识可能会引出对这个问题的进一步研究。

Keywords: affective commitment; customer engagement; customer satisfaction; customer perceived value; trust

全键词 : 情感承诺;顾客参与; 顾客满意度; 顾客感知价值; 信任 


\section{Introduction}

Customer engagement has emerged as an important construct in marketing research over the past decade (Islam \& Rahman, 2016, p. 2009). There appears to be a general agreement among marketing scholars that engaged customers could lead to a sustainable competitive advantage for the firm (Brodie, Ilic, Juric, \& Hollebeek, 2013; Hollebeek, 2012; Islam \& Rahman, 2016, p. 2008; Kumar \& Pansari, 2016). For instance, engaged customers may contribute to greater firm revenue (Kumar \& Pansari, 2016, p. 497). Hence, most research has focused on developing formal definitions for the customer engagement concept that may guide further exploration. Key contributions to the field include the work of Bowden (2009), who studied the concept from a psychological process perspective; Van Doorn et al. (2010), who defined the concept from a behavioural manifestation perspective; Brodie, Hollebeek, Jurić, and Ilić (2011), who believe the concept reflects a psychological state that occurs as a result of customer experiences; Vivek, Beatty, and Morgan (2012), who see the concept as the extent of a person's participation and connection with a firm; and Hollebeek (2011), who believes the concept reflects a customer's specific state of mind. After a systematic review of customer engagement research since 2005, Islam and Rahman (2016, p. 2019) concluded that the concept can be defined as 'the readiness of a customer to actively participate and interact with the focal object (e.g. brand/organization/community/website/organizational activity), [which] varies in direction (positive/negative) and magnitude (high/low) depending upon the nature of a customer's interaction with various touch points (physical/virtual).'

Among these different conceptualisations of customer engagement, there also appears to be an understanding that the construct is related to the establishment of relationships with customers and is therefore viewed as an expansion to the relationship marketing domain (So, King, Sparks, \& Wang, 2016, p. 9; Vivek et al., 2012, p. 128). However, little research has been conducted to further explore the connection between customer engagement and other 
relationship marketing constructs. In his strategic direction on the matter, Bolton (2011, p. 272) suggested an investigation into the relationship between established relationship marketing constructs, such as satisfaction, trust and customer value and customer engagement. Some attention has been given to these matters but there is still no consensus on the specific role of the stated relationship marketing factors within the customer engagement domain. One group of scholars believe customer satisfaction, trust, value and commitment (also a relationship marketing variable) should be perceived as consequences of customer engagement (Islam \& Rahman, 2016; Pansari \& Kumar, 2016; Vivek et al., 2012). Yet, another group of researchers indicate that the stated factors serve an antecedent role and contribute to customer engagement (Hollebeek, Srivastava, \& Chen, 2016; Islam \& Rahman, 2016; Pansari \& Kumar, 2016; Van Doorn et al., 2010). Supporting the second school of thought, Islam and Rahman (2016, p. 2020-2021) further indicate that it is also possible that factors such as satisfaction, trust, value and commitment, may be interrelated and jointly affect customer engagement. However, more research is required to explore these matters that have been overlooked in customer engagement research. Insight into these affairs may further be important, as customer engagement could contribute to a firm's competitive position.

This study then aims to contribute to the second research stream and further examine the interrelationship between customer satisfaction, trust, perceived value and commitment, and their ultimate effect on customer engagement. While the connection between these relationship marketing factors may have received some attention in earlier research, the findings of this study, as examined among a convenient sample of respondents, may provide an initial understanding of the interrelationships between key relationship marketing constructs and their ultimate effect on various customer engagement dimensions. These matters have received little attention in marketing research, and knowledge of the proposed relationships may lead to further research on this topic. 
From a managerial perspective, the research findings may also offer valuable guidance to short-term insurers in Gauteng, South Africa (the context of this study) to improve their customer engagement practices and obtain a competitive advantage. The South African shortterm insurance industry is regulated by the Financial Services Board (2015) and consists of seven reinsurers and 92 short-term insurers. The industry is regarded as well-developed and mature due to strong competition and the confidence South African consumers have in their local financial service providers. Collectively, Santam, Mutual \& Federal, Hollard and Outsurance hold the largest market share and underwrite $51.7 \%$ of the gross written premium of the short-term insurance market. Further growth is expected within the next few years as untapped segments - such as the lack Upwardly-Mobile Professionals (Buppies) - require exploration, and innovations (such as smartphones) may enhance online distribution and data mining possibilities (Maharaj, 2016). In spite of these developments, current insurance companies may be outsmarted by young, dynamic insurance providers taking advantage of digital transformation through mobile phones to enter the market (Terblanche, 2016). Furthermore, customers can easily switch between insurance companies due to the low cost in contracting another service provider (Mackay et al., 2015, p. 45). Hence, it has become imperative for short-term insurers to develop strategies that will foster greater customer engagement and enable the firms to maintain their market share.

In the sections that follow, a theoretical framework is first provided, which offers more insight into the relationship marketing constructs, customer engagement dimensions and research replications and hypotheses that are further explored in this study. This is followed by a discussion of the research methodology, the results and findings, and the theoretical and managerial implications of this study. The article concludes with an outline of the study's limitations and strategic directions for further research. 


\section{Theoretical framework}

\section{Relationship marketing}

Service firms can establish relationships with their customers (Morgan \& Hunt, 1994, p. 21) and so relationship marketing practices have been extensively studied within the services marketing domain (Brodie, 2017, p. 20). Seminal contributors have defined relationship marketing as 'attracting, maintaining and-in multi-service organizations-enhancing customer relationships' (Berry, 1983, p. 25), or 'attracting, developing, and retaining customer relationships' (Berry \& Parasuraman, 1991, p. 133). Berry (1983; 1995, p. 236) further suggests that firms practising relationship marketing should focus on the provision of a core service and must ensure the relationship is customised according to the individual's needs. Additionally, the core service must be enhanced with extra benefits and should be correctly priced to foster customer loyalty. Marketing initiatives must also be directed towards employees to ensure good service is provided to customers. Grönroos $(1994$, p. 9) believes that relationship marketing practices focus on two parts: attracting customers to the firm, and the subsequent building of relationships with these customers to accomplish the desired economic goals. However, established relationships can only be maintained and enhanced if promises made to customers are kept (Grönroos, 1994, p. 9). Therefore, relationship marketing is considered a viable tool for obtaining a sustainable competitive advantage (Jones et al., 2015, p. 188) and its relevance in the contemporary marketing environment is undisputed (Brodie, 2017; Gummerus, Von Koskull, \& Kowalkowski, 2017; Gummesson, 2017; Payne \& Frow, 2017; Sheth, 2017).

In the relationship marketing domain, relationship quality is considered an important concept that indicates the closeness or intensity of the relationship between a firm and its customers (Hajli, 2014, p. 19; Vesel \& Zabkar, 2010, p. 1336). While several factors attribute to relationship quality, customer satisfaction, trust and commitment are regarded as central 
components or predictors of relationship quality (Vesel \& Zabkar, 2010, p. 1336). Hence, for the purpose of this study, customer satisfaction, trust and commitment are further explored to determine their effect on customer engagement. In addition to these factors, customer perceived value is also examined as it is regarded as another key variable of relationship marketing (Roig, Garcia, Tena, \& Monzonis, 2006, p. 267).

\section{Customer satisfaction}

Customer satisfaction is described as 'the summary psychological state resulting when the emotion surrounding disconfirmed expectation is coupled with the consumer's prior feelings about the consumption experience' (Oliver, 1981). Satisfaction occurs when customers experience a positive disconfirmation of expectations or 'a pleasurable level of consumption related fulfilment' (Bowden, 2011, p. 214; Oliver, 1997). Hence, perceptions of customer satisfaction develop as a result of earlier interactions with a service provider (Bowden, 2011, p. 214). While it was initially thought that customer satisfaction involves an emotional process, marketing scholars have found that customer satisfaction comprises cognitive beliefs about the product and service, and affective feelings consumers develop towards the product or service received (Bagozzi, Gopinath, \& Nyer, 1999). Cognitive and affective evaluations are based on the consumption episodes experienced by customers (Bowden, 2011, p. 214). Some scholars also believe that customer satisfaction has a cumulative component, relating to the total evaluation of the service received as experienced by numerous service encounters (Narteh, 2015, p. 363). Customer satisfaction is receiving considerable attention in the financial services sector, owing to technological enhancements and competition within the industry. Financial firms attempt to differentiate themselves from competitors by facilitating greater satisfaction with the service (Liébana-Cabanillas, Muñoz-Leiva, \& Rejón-Guardia, 2013, p. 750). Customer satisfaction is also important within the South African short-term insurance industry as it is believed it could enhance relationship quality and contribute to the 
development of long-term relationships with customers (Mackay, Petzer, \& Mostert, 2014, p. 302, p. 320). Customer satisfaction is measured by examining the extent to which a customer believes that a wise purchase decision has been made, feels good about and is pleased with the purchase, and would recommend the product or service to other customers (Hellier, Geursen, Carr, \& Rickard, 2003).

\section{Trust}

Trust has been defined as 'a willingness to rely on an exchange partner in whom one has confidence' (Moorman, Deshpandé, \& Zaltman, 1993, p. 82). Trust is fundamental in relational exchanges between stakeholders. It is important as customers are expected to purchase services they have not yet experienced (Morgan \& Hunt, 1994, p. 24). Therefore, trust also relates to the perceived credibility and benevolence of the firm providing the service. Credibility trust denotes a customer's belief in the ability of the service firm to deliver services of high quality, while benevolence trust is associated with the customer's belief in the firm's ability to offer competent and reliable service (Kandampully, Zhang, \& Bilgihan, 2015, p. 393). Furthermore, trust relates to the degree to which the provider acts with integrity and honesty (Grabner-Kräuter \& Faullant, 2008, p. 486). It is argued that consumer trust results in benefits such as reduced risk and confidence (Bowden, 2009, p. 579). Perceptions of trust develop over time and are based on repeated interactions with a service provider (Shukla, Banerjee, \& Singh, 2016, p. 325). Mutual trust between stakeholders may result in tacit information sharing behaviour, non-opportunistic behaviour and the fostering of long-lasting partnerships (Chen, Wu, \& Chien, 2016, p. 94). Similar to customer satisfaction, consumer trust has also been identified as important in fostering ongoing relationships with customers in the financial services industry (Sekhon, Ennew, Kharouf, \& Devlin, 2014, p. 424). Consumer trust is measured by examining the extent to which the provider can be relied upon to keep its promises (integrity trust) and provide a good 
service (credibility trust), and puts the customer's interest first (benevolence trust) (Verhoef, Franses, \& Hoekstra, 2002).

\section{Customer commitment}

Morgan and Hunt (1994, p. 23) define commitment as 'an exchange partner believing that an ongoing relationship with another is so important as to warrant maximum efforts at maintaining'. According to Shukla et al. (2016, p. 324), commitment relates to the disincentive to change relationship partners. Generally, customer commitment is regarded as a complex construct that developed from the organisational behaviour/industrial organisation psychology literature; it is attitudinal in nature and relates to a person's feelings on taking part in certain behaviours (Fullerton, 2014, p. 659). Allen and Meyer (1990) say customer commitment comprises three components: affective commitment, continuance commitment and normative commitment. Affective commitment measures the feelings and emotional attachments customers may develop towards the firm providing the service. Continuance/calculative commitment assesses customers' inclination to remain with the service firm, owing to a lack of more beneficial alternatives. Customers who are normatively committed towards the service firm have a sense of obligation to remain in the relationship (Shukla et al., 2016, p. 324). Customer commitment is important in the financial services industry, especially the affective commitment dimension that is believed to contribute to greater customer retention and advocacy (Gustafsson, Johnson, \& Roos, 2005, p. 211; Menon \& O'Connor, 2007, p. 158). Affective commitment is measured by investigating the extent to which the customer is attached to the service provider, experiences a sense of belonging, and wants to remain a customer (Verhoef et al., 2002). 


\section{Customer perceived value}

Customer perceived value has been defined in different perspectives, including the pricebased study view (Monroe, 1979), the means-end theory view (Gutman, 1982; Zeithaml, 1988), and the utilitarian and hedonic value approach (Babin, Darden, \& Griffin, 1994; Holbrook \& Hirschman, 1982). Aligned with previous studies on the value in the insurance industry (Hellier et al., 2003), the means-end theory perspective and Zeithaml's (1988) definition of perceived value was adopted for the purpose of this study to guide further investigation. According to Zeithaml (1988), value perceptions are dependent on the price paid for a product offering, customer expectations of a product, the quality obtained in relation to the price paid as well as what consumers receive compared to what they have provided in the transaction (Sánchez-Fernández \& Iniesta-Bonillo, 2007, p. 432). According to Zeithaml (1988, p. 14), customer perceived value can be formally defined as 'the consumer's overall assessment of the utility of a product based on perceptions of what is received and what is given'. Customers will then base their decisions on product offerings that will maximise value and enable them to reap the highest payoff (Dootson, Beatson, \& Drennan, 2016, p. 12). Similar to the other relationship marketing factors investigated in this study, customer perceived value may also assist in contributing to a sustainable competitive advantage for a financial service firm (Dootson et al., 2016, p. 13). Considering Zeithaml's (1988) view of perceived value, the construct is measured by determining the extent to which the customer believes the price charged for a product or service is acceptable and low compared to other providers, and whether additional benefits are provided, and the product or service is flexible and sufficient to meet his or her needs (Hellier et al., 2003).

\section{Customer engagement dimensions}

As noted in the introduction, customer engagement is regarded as an expansion to the relationship marketing domain (So et al., 2016, p. 9; Vivek et al., 2012, p. 128) and may assist in obtaining a competitive advantage. This matter is especially important to the short-term insurance industry in South Africa that is challenged by low switching barriers for customers and young dynamic insurance companies taking advantage of digital transformation (Mackay et al., 2015, p. 45; Terblanche, 2016). According to Islam and Rahman (2016, p. 2019), while 
some scholars perceive customer engagement to be unidimensional, most authors have acknowledged the multidimensional nature of this concept. For the purpose of this study, the multidimensional approach of So, King and Sparks (2014, p. 304, p. 308) was adopted, as it is regarded suitable for a service business environment. So et al. (2014, p. 304, p. 308) propose that the customer engagement construct comprises five dimensions:

- Identification: refers to the degree to which a customer will relate to the object of engagement, which, in this study, may concern the short-term insurance provider. Customers who identify with a service provider may see critique of the provider as a personal insult to them, and view themselves as part of the company. These consumers also tend to identify themselves with the provider's success.

- Enthusiasm: concerns the extent to which consumers are excited about the focus of engagement. It is believed that enthusiastic consumers are keen and passionate about the provider.

- Attention: measures the customer's level of focus towards the object of engagement. Customers who are focused on the provider may want to learn more about it, pay attention to any aspect related to it, and concentrate extensively on the provider.

- Absorption: is perceived as a more progressive state of attention. Customers who are absorbed with their service provider will forget about anything else when interacting with them. They may get carried away and feel time flies when dealing with the provider. They may be deeply involved with the service provider and feel that it would be difficult to move away from them.

- Interaction: ascertains the extent to which customers partake in online or offline activities outside the purchase situation (So et al., 2014, p. 308-310). Customers may converse with other customers about the provider, and enjoy engaging with consumers similar to them who are also interested in the provider. 


\section{Conceptual model}

The conceptual model proposed for this study is presented in Figure 1.

Figure 1. Conceptual model.

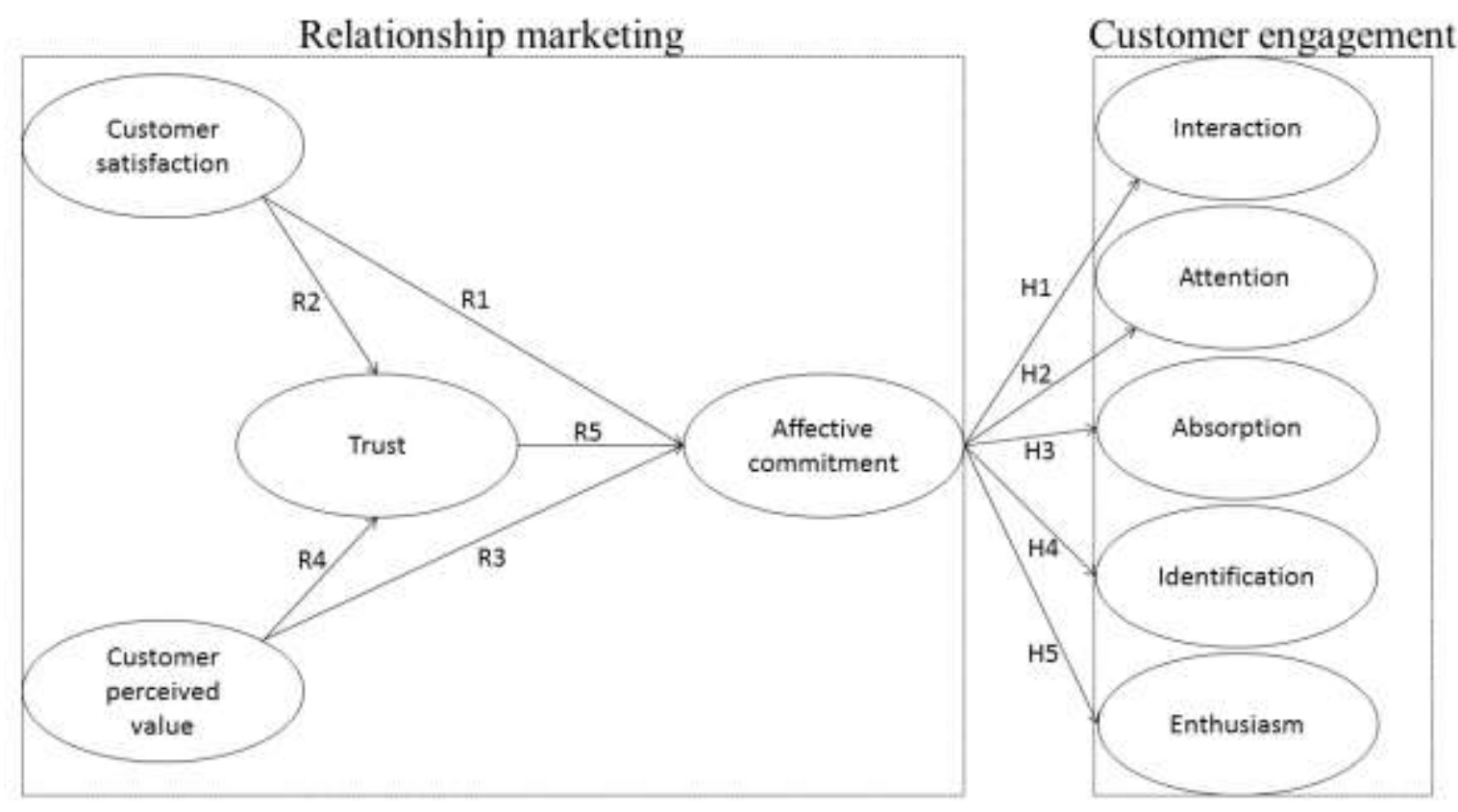

Considering the investigation of potential interaction effects between this study's relationship marketing constructs, it was first acknowledged that commitment plays a central role in relationship marketing (Morgan \& Hunt, 1994, p. 23; Wetzels, De Ruyter, \& Birgelen, 1998, p. 406). Commitment is also perceived as 'the most advanced phase of partners' interdependence', (Scanzoni, 1979; Wetzels et al., 1998, p. 408). Consequently, it was argued that the relationship marketing factors - customer satisfaction, trust and perceived value initially interact with each other and affect customer commitment. Committed customers may then become more engaged with the organisation.

Empirical support of the interaction effects between customer satisfaction, trust, perceived value and commitment can be found in various studies. For example, the relationship between customer satisfaction and commitment has been confirmed in the luxury motor vehicle industry (Van Tonder, Petzer, \& Van Zyl, 2017), as well as in media retailers 
and travel agencies industries (Hennig-Thurau, 2004). It is believed that customers who have experienced satisfactory performances will want to remain loyal to the organisation (Johnson, Sivadas \& Garbarino, 2008, p. 355). The extent to which customers are satisfied with the service may contribute to their future commitment to the service provider. Satisfied customers may become more committed to the service (Hennig-Thurau, 2004, p. 465). However, for the purpose of this study, only the affective commitment dimension was considered as it has been acknowledged in marketing literature as being strong in establishing consumer behaviour (Curth, Uhrich, \& Benkenstein, 2014, p. 148).

Hence, the following replication is presented concerning short-term insurance customers:

$\mathrm{R}_{1}$ : Customer satisfaction has a positive and significant impact on affective commitment.

According to Hess and Story (2005, p. 315), satisfaction and trust result from interactions between customers and service providers. Both satisfaction and trust contribute to the establishment of functional and personal connections, with trust primary building personal connections and satisfaction resulting in functional relationships. Satisfactory interactions with a service provider will lead to overall satisfaction and to trust in the service provider (Hess \& Story, 2005, p. 315; Moreira \& Silva, 2015, p. 262). Therefore, customer satisfaction has been found to have a positive effect on trust, as evidenced by studies conducted within the e-commerce (Kassim \& Abdullah, 2010), the business-to-business (Selnes, 1998) and the education industries (Schlesinger, Cervera, \& Pérez-Cabañero, 2016). As such, the following replication is presented concerning short-term insurance customers:

$\mathrm{R}_{2}$ : Customer satisfaction has a positive and significant impact on trust. 
Aurier and De Lanauze (2011, p. 815) propose a conceptual model where, among others, perceived value is considered to positively impact relationship quality constructs, including affective commitment, benevolence trust and credibility trust. This is further confirmed by a study in the telecommunications industry, where it was found that customer perceived value positively impacts affective commitment in the telecommunications industry (Johnson, Herrmann, \& Huber, 2006). Through the improvement of perceived value customers experience, affective commitment and loyalty intentions to a brand are positively influenced (Johnson et al., 2006, p. 130). The effect of customer perceived value on trust is also evident within the tourism (Silva \& Correia, 2016) and the wireless telecommunications industries (Karjaluoto, Jayawardhena, Leppäniemi, \& Pihlström, 2012). Subsequently, the following replications are presented concerning short-term insurance customers:

$\mathrm{R}_{3}$ : Customer perceived value has a positive and significant impact on affective commitment.

$\mathrm{R}_{4}$ : Customer perceived value has a positive and significant impact on trust.

Previous studies have additionally found a positive and significant relationship between trust and customer commitment within the luxury motor vehicle (Van Tonder et al., 2017), the business-to-business (Morgan \& Hunt, 1994) and the hospitality industries (Li \& Chang, 2016). Trust is believed to reduce perceived risk and thereby enhance a customer's commitment to the provider. Customers are confident that problems will be resolved in time, which subsequently reduces the transaction cost involved (So et al., 2014, p. 4). Thus, the following replication is presented concerning short-term insurance customers:

$\mathrm{R}_{5}$ : Trust has a positive and significant impact on affective commitment. Considering the relationship between commitment and customer engagement, it has been established that committed customers may become engaged with the organisation (Islam \& Rahman, 2016, p. 2021). However, individual relationships between affective commitment 
and the various sub-dimensions of customer engagement have not been explored before. Brodie et al. (2011, p. 254-255) profess that a unidimensional approach to the customer engagement construct allows for straightforwardness; while studying customer engagement from a multidimensional perspective allows for richer insight into customer engagement.

Consequently, this study is interested in the possibility that affective commitment may have a positive and significant relationship with the various sub-dimensions of customer engagement. Support for these relationships can be found by acknowledging the characteristics of the affective commitment construct. Specifically, it is plausible that affectively committed individuals (consumers) may identify with an organisation to who they feel emotionally attached (customer engagement identification). It has previously been stated that affectively committed individuals tend to be emotionally attached towards the organisation. They identify with the organisation and are involved in its activities (Meyer et al., 2002, p. 21). Cater and Zakbar (2009, p. 787) similarly acknowledge that affective commitment "stems from identification, shared values, belongingness, dedication and similarity". Furthermore, affectively committed individuals have a desire to maintain, develop and strengthen a relationship with another party (Marinkovic \& Obradovic, 2015, p. 248), as they perceive the relationship to be of value (Evanschitzky, Iyer \& Plassmann, 2006, p. 1208). Thus, the positive emotions customers feel towards the organisation may result in enthusiasm, attention towards the activities of the organisation and being deeply involved in these activities (absorption), as demonstrated by their dedication towards the organisation and their desire to maintain and enhance their relationships with the organisation which they value. Customers may also take ownership and interact with other customers about the service provider. As noted by earlier studies, customers who are emotionally attached to the brand, tend to take ownership and will discuss the brand with other customers (Pansari \& Kumar, 
2017, p. 304; Fullerton, 2005, p. 97). These relationships require further investigation and as such it is hypothesised in the context of this study that:

$\mathrm{H}_{1}$ : Affective commitment has a positive and significant impact on the interaction dimension of customer engagement.

$\mathrm{H}_{2}$ : Affective commitment has a positive and significant impact on the attention dimension of customer engagement.

$\mathrm{H}_{3}$ : Affective commitment has a positive and significant impact on the absorption dimension of customer engagement.

$\mathrm{H}_{4}$ : Affective commitment has a positive and significant impact on the identification dimension of customer engagement.

$\mathrm{H}_{5}$ : Affective commitment has a positive and significant impact on the enthusiasm dimension of customer engagement.

\section{Methodology}

The study followed an explanatory research design that is quantitative, as the interrelationships between several variables were investigated (Saunders \& Lewis, 2012). The sample size of 500 respondents was predicted and the target population included customers of short-term insurance providers who live in Gauteng, South Africa. A research frame of the target population was not available. Subsequently, a multiple non-probability sampling technique was followed to select the sample. Respondents were approached on the basis of convenience, while aiming to fill quotas based on age and gender. Filling these quotas allowed the sample to include an equal number of male and female respondents and for respondents to be of different age categories, ranging from 18 to 21 years old, 22 to 39 years old, 40 to 52 years old, and older than 53 years old. Furthermore, it is acknowledged in this study that the selection of a convenience sample method affected the external validity of the research findings, referring to the extent to which the findings are representative of the entire 
population and may be generalised to other samples, time zones and settings (Ihantola \& Kihn, 2011, p. 42; Calder, Phillips \& Tybout, 1982, p. 240). Ihantola and Kihn (2011, p. 42) noted that external validity is threatened by the extent to which the research findings are useful in representing the views of the entire population, whether similar findings may be obtained in different time periods and if the results can be generalised to other environments, such as different countries. Because the respondents in this study were selected on the basis of convenience, the research findings will not be representative of the views of the entire population, and it would not be possible the generalise the findings to other samples, time zones and settings.

Considering the purpose of this study, the lack of external validity of the research findings, however, is not a primary concern. As noted by Landers and Behrend (2015, p. 147), if the research question relate to whether a phenomenon can occur, instead of, for example, verifying the frequency of occurrence, the internal validity of the research findings is of greater importance than the external validity. Accordingly, with the aim of providing initial insight into the interrelationships between relationship marketing constructs and customer engagement dimensions, this study followed a convenience sampling approach and concentrated on proving the internal validity of the research data.

A self-administered questionnaire containing mostly structured closed-ended questions was used to collect data. The questionnaire uncovers the demographic profile and short-term insurance provider patronage habits of respondents with questions adopted from Mackay (2013). Existing scales that were proven valid and reliable in previous studies were adapted for the purpose of this study. Table 1 provides insight into the measures used. Each of the items presented in Table 1 was measured on a five-point scale where one represents strongly disagree and five represents strongly agree. Customer satisfaction and customer value were measured using measures adapted from Hellier et al. (2003), and assessed all the 
components of the constructs as discussed in the literature review. Trust and affective commitment were measured using measures adapted from Verhoef et al. (2002). While trust focused on the credibility, benevolence and integrity components, only the affective component of customer commitment was considered for this study. As mentioned in the previous section, this dimension is strong in establishing consumer behaviour (Curth et al., 2014, p. 148). Customer engagement was measured across five dimensions with a measure adapted from So et al. (2014).

Table 1. Measures used in the study.

\begin{tabular}{|c|c|c|c|}
\hline Construct/ dimension & Item & $\begin{array}{l}\text { Item } \\
\text { code }\end{array}$ & Source \\
\hline \multirow[t]{4}{*}{ Customer satisfaction } & $\begin{array}{l}\text { My decision to purchase insurance from my short-term } \\
\text { insurance provider was a wise one. }\end{array}$ & CS1 & \multirow[t]{4}{*}{$\begin{array}{l}\text { Hellier et al. } \\
(2003)\end{array}$} \\
\hline & $\begin{array}{l}\text { I feel good about my decision to purchase insurance from } \\
\text { my short-term insurance provider. }\end{array}$ & $\mathrm{CS} 2$ & \\
\hline & $\begin{array}{l}\text { I am pleased I purchased insurance from my short-term } \\
\text { insurance provider. }\end{array}$ & CS3 & \\
\hline & $\begin{array}{l}\text { I would positively recommend my short-term insurance } \\
\text { provider to other people. }\end{array}$ & CS4 & \\
\hline \multirow[t]{6}{*}{ Customer value } & $\begin{array}{l}\text { The cost of my short-term insurance premium is low } \\
\text { compared to other short-term insurance providers. }\end{array}$ & CV1 & \multirow[t]{6}{*}{$\begin{array}{l}\text { Hellier et al. } \\
(2003)\end{array}$} \\
\hline & $\begin{array}{l}\text { The flexibility of my short-term insurance provider's } \\
\text { product and service offerings is sufficient to meet my } \\
\text { needs. }\end{array}$ & $\mathrm{CV} 2$ & \\
\hline & $\begin{array}{l}\text { My short-term insurance provider provides additional } \\
\text { financial benefits and assistance. }\end{array}$ & CV3 & \\
\hline & $\begin{array}{l}\text { I can readily understand the exclusions in the insurance } \\
\text { policy document I received from my short-term insurance } \\
\text { provider. }\end{array}$ & CV4 & \\
\hline & $\begin{array}{l}\text { I regard the policy premium I pay to my short-term } \\
\text { insurance provider as acceptable. }\end{array}$ & CV5 & \\
\hline & $\begin{array}{l}\text { I consider the policy I have with my short-term insurance } \\
\text { provider to be a good purchase. }\end{array}$ & CV6 & \\
\hline \multirow[t]{4}{*}{ Trust } & $\begin{array}{l}\text { My short-term insurance provider can be relied on to keep } \\
\text { its promises to me. }\end{array}$ & TR1 & \multirow[t]{4}{*}{$\begin{array}{l}\text { Verhoef et } \\
\text { al. }(2002)\end{array}$} \\
\hline & My short-term insurance provider puts me first. & TR2 & \\
\hline & $\begin{array}{l}\text { My short-term insurance provider usually keeps the } \\
\text { promises that it makes to me. }\end{array}$ & TR3 & \\
\hline & $\begin{array}{l}\text { I can count on my short-term insurance provider to provide } \\
\text { a good service to me. }\end{array}$ & TR4 & \\
\hline \multirow[t]{3}{*}{ Affective commitment } & I am a loyal customer of my short-term insurance provider. & $\mathrm{AC} 1$ & \multirow{3}{*}{$\begin{array}{l}\text { Verhoef et } \\
\text { al. (2002) }\end{array}$} \\
\hline & $\begin{array}{l}\text { Because I feel a strong attachment to my short-term } \\
\text { insurance provider, I want to remain a customer of my } \\
\text { short-term insurance provider. }\end{array}$ & $\mathrm{AC} 2$ & \\
\hline & $\begin{array}{l}\text { Because I feel a strong sense of belonging with my short- } \\
\text { term insurance provider, I want to remain a customer of my } \\
\text { short-term insurance provider. }\end{array}$ & $\mathrm{AC} 3$ & \\
\hline $\begin{array}{l}\text { Customer engagement } \\
\text { (interaction) }\end{array}$ & $\begin{array}{l}\text { I like to get involved in discussions about my short-term } \\
\text { insurance provider with other people who are also }\end{array}$ & CEINT1 & $\begin{array}{l}\text { So et al. } \\
(2014)\end{array}$ \\
\hline
\end{tabular}




\begin{tabular}{|c|c|c|}
\hline & interested in my insurer. & \\
\hline & $\begin{array}{l}\text { I am someone who enjoys interacting with like-minded } \\
\text { people who are also interested in my insurer. }\end{array}$ & CEINT2 \\
\hline & $\begin{array}{l}\text { I like to actively participate in discussions with other } \\
\text { people who are also interested in my insurer. }\end{array}$ & CEINT3 \\
\hline & $\begin{array}{l}\text { I thoroughly enjoy exchanging ideas with other people who } \\
\text { are also interested in my insurer. }\end{array}$ & CEINT4 \\
\hline & $\begin{array}{l}\text { I often participate in activities with other people also } \\
\text { interested in my insurer. }\end{array}$ & CEINT5 \\
\hline \multirow[t]{5}{*}{$\begin{array}{l}\text { Customer engagement } \\
\text { (attention) }\end{array}$} & $\begin{array}{l}\text { I like to learn more about my short-term insurance } \\
\text { provider. }\end{array}$ & CEATT1 \\
\hline & $\begin{array}{l}\text { I pay a lot of attention to anything related to my short-term } \\
\text { insurance provider. }\end{array}$ & CEATT2 \\
\hline & $\begin{array}{l}\text { Anything related to my short-term insurance provider grabs } \\
\text { my attention. }\end{array}$ & CEATT3 \\
\hline & I concentrate a lot on my short-term insurance provider. & CEATT4 \\
\hline & $\begin{array}{l}\text { I like learning more about my short-term insurance } \\
\text { provider. }\end{array}$ & CEATT5 \\
\hline \multirow[t]{6}{*}{$\begin{array}{l}\text { Customer engagement } \\
\text { (absorption) }\end{array}$} & $\begin{array}{l}\text { When I am interacting with my short-term insurance } \\
\text { provider, I forget everything else around me. }\end{array}$ & CEABS1 \\
\hline & $\begin{array}{l}\text { Time flies when I am interacting with my short-term } \\
\text { insurance provider. }\end{array}$ & CEABS2 \\
\hline & $\begin{array}{l}\text { When I am interacting with my short-term insurance } \\
\text { provider, I get carried away. }\end{array}$ & CEABS3 \\
\hline & $\begin{array}{l}\text { When I am interacting with my short-term insurance } \\
\text { provider, it is difficult to get away from it. }\end{array}$ & CEABS4 \\
\hline & $\begin{array}{l}\text { In my interaction with my short-term insurance provider, I } \\
\text { am deeply involved. }\end{array}$ & CEABS5 \\
\hline & $\begin{array}{l}\text { When interacting with my short-term insurance provider } \\
\text { intensely, I feel happy. }\end{array}$ & CEABS6 \\
\hline \multirow[t]{4}{*}{$\begin{array}{l}\text { Customer engagement } \\
\text { (identification) }\end{array}$} & $\begin{array}{l}\text { When someone criticises my short-term insurance provider, } \\
\text { it feels like a personal insult. }\end{array}$ & CEID1 \\
\hline & $\begin{array}{l}\text { In a conversation involving my short-term insurance } \\
\text { provider, I usually refer to the insurer as 'we' rather than } \\
\text { 'they'. }\end{array}$ & CEID2 \\
\hline & $\begin{array}{l}\text { I see my short-term insurance provider's successes also as } \\
\text { my successes. }\end{array}$ & CEID3 \\
\hline & $\begin{array}{l}\text { When someone praises my short-term insurance provider, it } \\
\text { feels like a personal compliment. }\end{array}$ & CEID4 \\
\hline \multirow{5}{*}{$\begin{array}{l}\text { Customer engagement } \\
\text { (enthusiasm) }\end{array}$} & I am very keen about my short-term insurance provider. & CEEN1 \\
\hline & I am passionate about my short-term insurance provider. & CEEN2 \\
\hline & I am enthusiastic about my short-term insurance provider. & CEEN3 \\
\hline & I feel excited about my short-term insurance provider. & CEEN4 \\
\hline & I love my short-term insurance provider. & CEEN5 \\
\hline
\end{tabular}

Prior to the execution of the field study, the questionnaire was presented to a panel of marketing experts with characteristics similar to this study's target population. The panel was in agreement that the previously validated measurement scales adapted for this study were suitable for inclusion in the investigation. Trained fieldworkers were then used to identify and screen possible respondents, and to ensure only customers of short-term insurance providers, 
who live in Gauteng, South Africa, participate in the study. Respondents were approached in public places and invited to participate in the study. Those who were eligible to partake in the study were asked to complete the self-administered questionnaire once the nature of the study and the rights of the respondents, as contained in the introduction of the questionnaire, were explained by the fieldworker. The fieldworker then arranged to collect the completed questionnaire. The researchers controlled the filling of quotas and quality of responses received. Data was collected over a three-week period during February and March 2016. A total of 491 questionnaires were initially obtained. However, two of the questionnaires contained many missing responses where some questions were not fully completed and were subsequently omitted from the survey. Therefore the final realised sample was 489 , out of the 500 responses as proposed in the sampling plan of the study. The 489 questionnaires that were retained contained no missing data.

SPSS version 24 was initially used to analyse the data. After the data was entered and cleaned, frequencies and descriptive statistics (means and standard deviations) were calculated to describe the demographics and patronage habits of respondents. Means and standard deviations were also calculated and the reliability statistics (Cronbach's alphas) were determined. An exploratory factor analysis (EFA) was conducted to explore the underlying relationships between the items included in the measures of the customer engagement construct. AMOS version 24 was then used for covariance-based structural equation modelling (SEM) to estimate the measurement and structural model proposed for the study. Maximum likelihood estimation was used to calculate the model parameters. 


\section{Results}

\section{Demographics and patronage habits}

It is evident from Table 2 that the respondents are equally distributed regarding gender: 49.7\% male and 50.3\% female. The respondents are spread across different age categories with most of them belonging to the 22 to 39 years old category (46.0\%), followed by the 40 to 52 years old category $(29.7 \%)$. Considering race, $38.9 \%$ of respondents are white, while $35.0 \%$ of respondents are black.

Table 2. Demographics of respondents.

\begin{tabular}{llll}
\hline Variable & Category & Frequency & Percentage \\
\hline Gender & Male & 243 & $49.7 \%$ \\
& Female & 246 & $50.3 \%$ \\
Age & 21 years and younger & 13 & $2.7 \%$ \\
& 22 to 39 years & 225 & $46.0 \%$ \\
& 40 to 52 years & 145 & $29.7 \%$ \\
Race & 53 years and older & 106 & $21.7 \%$ \\
& White & 190 & $38.9 \%$ \\
& Black & 171 & $35.0 \%$ \\
& Coloured & 24 & $4.9 \%$ \\
& Indian & 100 & $20.4 \%$ \\
& Asian & 4 & $0.8 \%$ \\
\hline
\end{tabular}

In total, the respondents selected 33 different short-term insurance providers with whom they do most of their business (accounting for monthly premiums). As per Table 3, the short-term insurance provider most selected is Outsurance (19.8\%) followed by Santam (11.5\%) and Mutual \& Federal $(11.0 \%)$. A total of $92.0 \%$ of respondents indicated that they had their vehicles insured with one of the short-term insurance providers followed by household insurance $(55.4 \%)$ and home owner's insurance $(41.5 \%)$. On average, respondents have been a part of their short-term insurance providers for five years - spending, on average, R1 679.58 per month on insurance premiums. 
Table 3. Patronage habits of respondents.

\begin{tabular}{llll}
\hline Variable & Category & Frequency & Percentage \\
\hline Top five short-term insurance providers & Outsurance & 97 & $19.8 \%$ \\
& Santam & 56 & $11.5 \%$ \\
& Mutual \& Federal & 54 & $11.0 \%$ \\
& MiWay & 50 & $10.2 \%$ \\
& Hollard & 40 & $8.2 \%$ \\
Items insured & Vehicle insurance & 450 & $92.0 \%$ \\
& Home owner's insurance & 203 & $41.5 \%$ \\
& Household insurance Other & 271 & $55.4 \%$ \\
& & 30 & $6.1 \%$ \\
\hline Variable & & SD & Mean \\
\hline Time with short-term insurance provider & & 4.67 years & 5 years \\
Monthly short-term insurance premium & & R2372.23 & R1679.58 \\
\hline
\end{tabular}

\section{Exploring the underlying structure of the measures used}

Prior to the assessment of the measurement model, it was necessary to first verify the underlying relationships between the items in the customer engagement construct, which consists of several sub-dimensions. An EFA was conducted that included a principal component analysis to extract the factors, with varimax rotation (orthogonal rotation) to rotate the factor solutions.

The findings showed that, for the customer engagement construct, the Kaiser-MeyerOlkin Measure of Sampling Adequacy exceeds the 0.6 cut-off point (0.947), and the p-value for the Bartlett's Test of Sphericity is significant at $p<0.0001$ (Bartlett, 1954; Kaiser, 1974). Table 4 presents the results of the rotated component matrix. The factor loadings in bold were retained for further analysis, as they were all above 0.5 and represent the highest or only factor loadings produced for the relevant measurement items. Furthermore, it can be observed from Table 4 that, for the customer engagement construct, four factors were extracted instead of the five dimensions identified by So et al. (2014). The first factor extracted the highest variance $(48.91 \%)$, followed by the second factor $(14.31 \%)$, the third factor $(7.84 \%)$, and the fourth factor $(6.92 \%)$. In addition, two of the original dimensions (identification and enthusiasm) appeared to have merged into one factor. One item under the customer engagement absorption construct (CEABS6) also loaded under the first factor. Accordingly, 
for this study, a new customer engagement sub-dimension, namely 'customer engagement affection' was created. Affection relates to 'a feeling of liking and caring for someone or something' (Affection, 2017). This theme appears to be generic among all the items that loaded under the first factor and that were retained. Further to this decision, the investigation of $\mathrm{H}_{4}$ and $\mathrm{H}_{5}$ became immaterial and these two hypotheses were omitted from further analysis. A new hypothesis $\mathrm{H}_{4 \text { (revised) }}$ was formulated, stating that affective commitment has a positive and significant impact on the affection dimension of customer engagement of shortterm insurance customers.

Table 4. Rotated component matrix.

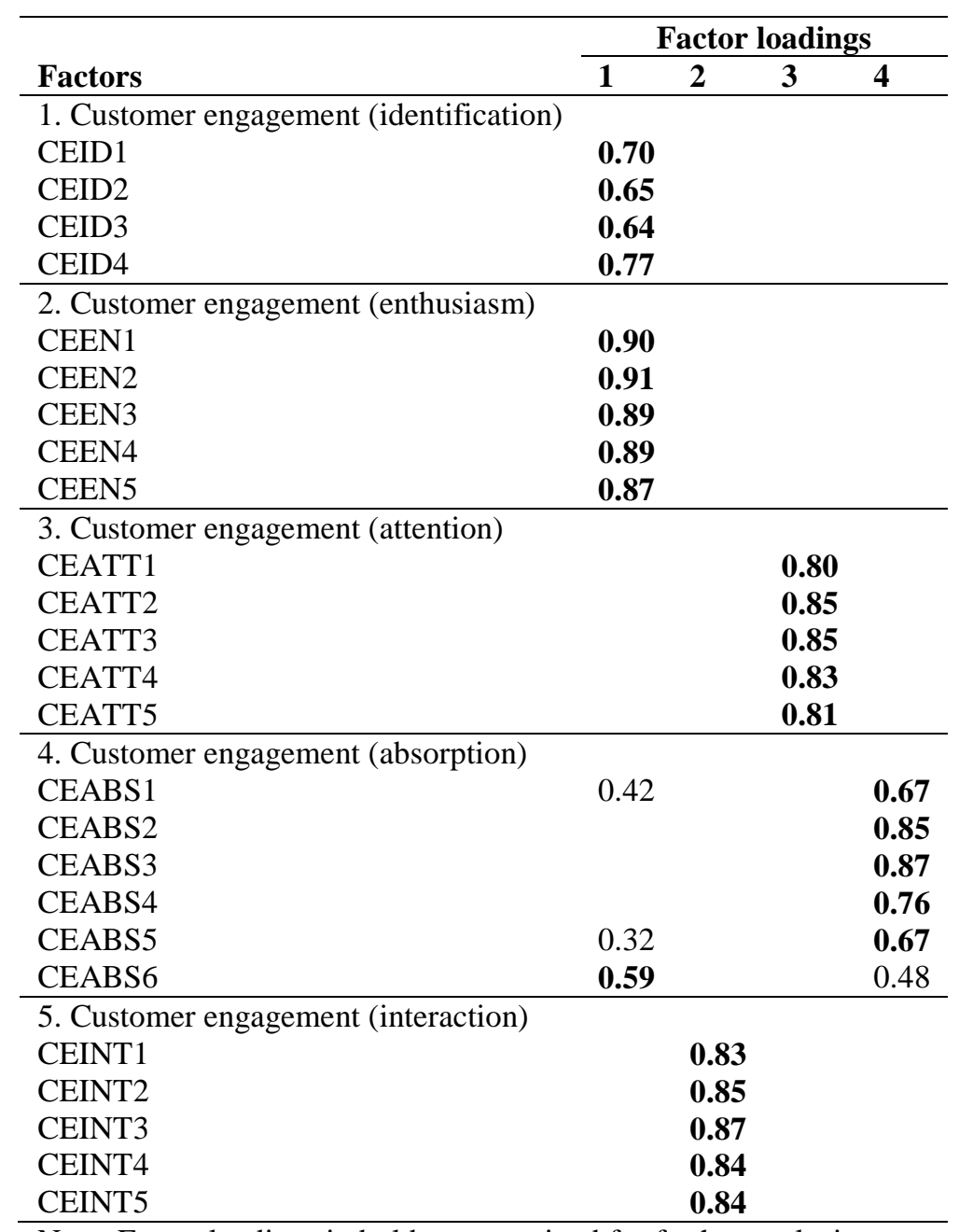

Note: Factor loadings in bold were retained for further analysis. 


\section{Measurement model}

Thereafter, a confirmatory factor analysis (CFA) was conducted to estimate the appropriateness of the measurement model. The measurement model comprised of the four customer engagement factors and their underlying items as identified from the EFA, as well as the relationship marketing constructs also investigated in this study (customer satisfaction, customer perceived value, trust and affective commitment). Upon inspection of the initial results, the decision was made to remove all items that had factor loadings below the cut-off value of 0.7, as recommended by Hair, Black, Babin, and Anderson (2014) for obtaining good construct validity. The items that were removed include CV1, CV3, CV4, CEABS1, CEID2, CEID3, CEAB6 and CEID1. The re-specified measurement model executed successfully and delivered a GFI estimate of 0.844 and an AGFI estimate of 0.815 . These scores fall within the 0.80 to 0.89 range and accordingly is considered illustrative of a reasonable model fit (Doll, Xia \& Torkzadeh, 1994, p. 456). The root mean square error of approximation (RMSEA) was determined as a second absolute fit index. According to Hair et al. (2014, p. 579), this statistic is widely used among researchers and "better represents how well a model fits a population, not just a sample used for estimation. It explicitly tries to correct for both model complexity and sample size by including each in its computation". Hence it is regarded as "one of the most informative fit indices" and takes into consideration optimal parameter values (Diamantopoulos \& Siguaw, 2000, p. 85). Adequate results were delivered. An RMSEA estimate of 0.066 was attained that is lower than the maximum cutoff value of 0.08 , as recommended by Hair et al. (2014:579). Additionally, the following fit statistics provided further support of adequate model fit (Hair et al, 2014): NFI (0.920), RFI (0.911), IFI (0.945), TLI (0.938), CFI (0.944) and CMIN/DF ratio (3.11).

Table 5 presents a summary of the latent factor correlations and corresponding average variance extracted (AVE) values obtained for each construct. 
Table 5. Correlation matrix with AVE on the diagonal.

\begin{tabular}{lcccccccc}
\hline Latent variables & $\mathbf{1}$ & $\mathbf{2}$ & $\mathbf{3}$ & $\mathbf{4}$ & $\mathbf{5}$ & $\mathbf{6}$ & $\mathbf{7}$ & $\mathbf{8}$ \\
\hline 1.Customer satisfaction & $(0.81)$ & & & & & & & \\
2. Customer perceived value & 0.77 & $(0.64)$ & & & & & & \\
3. Trust & 0.81 & 0.79 & $(0.76)$ & & & & & \\
4. Affective commitment & 0.66 & 0.66 & 0.71 & $(0.80)$ & & & & \\
5. Customer engagement (interaction) & 0.50 & 0.44 & 0.51 & 0.42 & $(0.87)$ & & & \\
6. Customer engagement (attention) & 0.34 & 0.35 & 0.31 & 0.29 & 0.60 & $(0.77)$ & & \\
7. Customer engagement (absorption) & 0.21 & 0.25 & 0.19 & 0.17 & 0.52 & 0.54 & $(0.68)$ & \\
8. Customer engagement (affection) & 0.54 & 0.61 & 0.64 & 0.64 & 0.52 & 0.41 & 0.30 & $(0.82)$ \\
\hline
\end{tabular}

All correlations are statistically significant at $p<0.001$; AVE values are presented in brackets on the diagonal.

From Table 5 it is evident that all correlations between the latent constructs are positive and significant $(p<0.001)$. Furthermore, the AVE values for each construct are greater than the squared correlation coefficients between the respective constructs. For example, the squared correlation coefficient for the relationship between customer satisfaction and trust is 0.66 ; while the AVE value for customer satisfaction and trust is 0.81 and 0.76 , respectively. As indicated in Table 6, the maximum shared variance (MSV) values for all constructs are greater than their respective average shared variance (ASV) values, but smaller than the corresponding AVE values. Therefore, sufficient evidence of discriminant validity was provided (Fornell \& Larcker, 1981; Hair et al., 2014).

Table 6 shows that the means for the measurement items range between 2.42 and 3.70, and the standard deviations range between 0.87 and 1.28. These results indicate some regularity between the items and the constructs measured.

Other aspects addressed in Table 6 include the standardised factor loadings for each construct obtained from the CFA, as well as the item-total correlations, the Cronbach's alpha values, and the composite reliability $(\mathrm{CR})$ values. All factors loaded significantly onto their respective constructs $(p<0.001)$. Furthermore, all item-total correlations are greater than 0.3 (Pallant 2013 p. 104) and all standardised factor loadings are greater than 0.7, except for CV2 (0.68) that was retained, as the item loading is significant and the customer perceived value construct comprises only three measurement items. 
Table 6. Assessment of the constructs of the study.

\begin{tabular}{|c|c|c|c|c|c|c|c|c|c|c|}
\hline Construct/ dimension & Item & $\begin{array}{l}\text { Factor } \\
\text { loading }\end{array}$ & $\begin{array}{c}\text { Item-total } \\
\text { correlations }\end{array}$ & Mean & SD & $\begin{array}{c}\text { Cronbach's alpha if item } \\
\text { deleted }\end{array}$ & CR & $\begin{array}{c}\text { Cronbach's } \\
\text { alpha }\end{array}$ & ASV & MSV \\
\hline \multirow{4}{*}{ Customer satisfaction } & CS1 & 0.87 & 0.84 & 3.70 & 0.93 & 0.93 & \multirow{4}{*}{0.94} & \multirow{4}{*}{0.94} & \multirow{4}{*}{0.34} & \multirow{4}{*}{0.66} \\
\hline & $\mathrm{CS} 2$ & 0.94 & 0.91 & 3.64 & 0.92 & 0.91 & & & & \\
\hline & $\mathrm{CS} 3$ & 0.94 & 0.90 & 3.62 & 0.94 & 0.91 & & & & \\
\hline & CS4 & 0.84 & 0.80 & 3.57 & 0.93 & 0.94 & & & & \\
\hline \multirow{3}{*}{ Customer perceived value } & CV2 & 0.68 & 0.60 & 3.28 & 0.94 & 0.85 & \multirow{3}{*}{0.84} & \multirow{3}{*}{0.83} & \multirow{3}{*}{$\mathbf{0 . 3 4}$} & \multirow{3}{*}{0.62} \\
\hline & CV5 & 0.83 & 0.75 & 3.29 & 0.93 & 0.71 & & & & \\
\hline & CV6 & 0.88 & 0.73 & 3.51 & 0.90 & 0.73 & & & & \\
\hline \multirow{4}{*}{ Trust } & TR1 & 0.89 & 0.84 & 3.46 & 0.95 & 0.90 & \multirow{4}{*}{0.93} & \multirow{4}{*}{0.93} & \multirow{4}{*}{$\mathbf{0 . 3 7}$} & \multirow{4}{*}{0.66} \\
\hline & TR2 & 0.84 & 0.80 & 3.24 & 0.99 & 0.91 & & & & \\
\hline & TR3 & 0.88 & 0.85 & 3.42 & 0.87 & 0.90 & & & & \\
\hline & TR4 & 0.87 & 0.83 & 3.52 & 0.90 & 0.90 & & & & \\
\hline \multirow{3}{*}{ Affective commitment } & $\mathrm{AC} 1$ & 0.76 & 0.73 & 3.43 & 1.04 & 0.95 & \multirow{3}{*}{0.92} & \multirow{3}{*}{0.91} & \multirow{3}{*}{$\mathbf{0 . 3 0}$} & \multirow{3}{*}{$\mathbf{0 . 5 1}$} \\
\hline & $\mathrm{AC} 2$ & 0.98 & 0.91 & 3.13 & 1.22 & 0.80 & & & & \\
\hline & $\mathrm{AC} 3$ & 0.92 & 0.86 & 3.06 & 1.25 & 0.85 & & & & \\
\hline \multirow{5}{*}{$\begin{array}{l}\text { Customer engagement } \\
\text { (interaction) }\end{array}$} & CEINT1 & 0.93 & 0.90 & 2.76 & 1.18 & 0.96 & \multirow{5}{*}{0.97} & \multirow{5}{*}{0.97} & \multirow{5}{*}{0.26} & \multirow{5}{*}{0.36} \\
\hline & CEINT2 & 0.95 & 0.93 & 2.78 & 1.18 & 0.96 & & & & \\
\hline & CEINT3 & 0.96 & 0.94 & 2.78 & 1.17 & 0.96 & & & & \\
\hline & CEINT4 & 0.94 & 0.92 & 2.71 & 1.18 & 0.96 & & & & \\
\hline & CEINT5 & 0.89 & 0.87 & 2.60 & 1.20 & 0.97 & & & & \\
\hline \multirow{5}{*}{ Customer engagement (attention) } & CEATT1 & 0.78 & 0.78 & 3.36 & 1.11 & 0.94 & & & & \\
\hline & CEATT2 & 0.90 & 0.86 & 3.29 & 1.15 & 0.93 & & & & \\
\hline & CEATT3 & 0.93 & 0.88 & 3.27 & 1.15 & 0.92 & 0.94 & 0.94 & 0.18 & 0.36 \\
\hline & CEATT4 & 0.92 & 0.87 & 3.03 & 1.16 & 0.92 & & & & \\
\hline & CEATT5 & 0.84 & 0.83 & 3.26 & 1.13 & 0.93 & & & & \\
\hline & CEABS2 & 0.89 & 0.82 & 2.49 & 1.15 & 0.82 & & & & \\
\hline Customer engagement & CEABS3 & 0.93 & 0.86 & 2.42 & 1.08 & 0.81 & & & & \\
\hline (absorption) & CEABS4 & 0.76 & 0.69 & 2.67 & 1.28 & 0.87 & 0.89 & 0.88 & 0.12 & 0.29 \\
\hline & CEABS5 & 0.70 & 0.63 & 2.65 & 1.15 & 0.89 & & & & \\
\hline & CEID4 & 0.72 & 0.72 & 2.46 & 1.26 & 0.97 & & & & \\
\hline & CEEN1 & 0.90 & 0.89 & 2.88 & 1.15 & 0.95 & & & & \\
\hline & CEEN2 & 0.96 & 0.94 & 2.68 & 1.16 & 0.95 & & & & \\
\hline Customer engagement (affection) & CEEN3 & 0.96 & 0.93 & 2.78 & 1.15 & 0.95 & $\mathbf{0 . 9 7}$ & 0.96 & 0.29 & 0.41 \\
\hline & CEEN4 & 0.96 & 0.93 & 2.76 & 1.15 & 0.95 & & & & \\
\hline & CEEN5 & 0.91 & 0.88 & 2.74 & 1.18 & 0.95 & & & & \\
\hline
\end{tabular}

Note: All factors loaded significantly at $p<0.001$. 
Considering that all AVE values are greater than 0.5 and the CR value for each construct is greater than 0.7, there is also evidence of convergent validity (Byrne, 1998; Fornell \& Larcker, 1981; Hair et al., 2014). Finally, considering that the overall Cronbach's alpha value for each construct is greater than 0.7, and the individual Cronbach's alpha values remained fairly consistent above the cut-off value even if items are deleted, evidence is also provided of good reliability and internal consistency of the research constructs (DeVellis 2012; Tabachnick \& Fidell, 2001).

\section{Structural model}

The structural model was developed next. Upon initial inspection of the results it became evident that modifications were required to obtain reasonable model fit. Specifically, the modification indices indicated that the errors of the latent variables interaction, attention, absorption and affection could be co-varied to improve model fit and deliver a valid SEM model that falls within the parameters specified for structural equation modelling (Hair et al 2014). Subsequently, these covariances were added. They were deemed theoretically relevant, as the four factors all represent dimensions of the customer engagement construct. The revised SEM model statistics are presented in Table 7.

The re-specified SEM model delivered a GFI estimate of 0.833 and an AGFI estimate of 0.806. Again, these scores fall within the 0.80 to 0.89 range and accordingly is considered illustrative of a reasonable model fit (Doll, Xia \& Torkzadeh, 1994, p. 456). The RMSEA estimate (second absolute fit index) is 0.068 and was deemed adequate as it is lower than the maximum cutoff value of 0.08 , as recommended by Hair et al. (2014:579). The following fit statistics provided further support of adequate model fit (Hair et al, 2014): NFI (0.915), RFI (0.906), IFI (0.939), TLI (0.933), CFI (0.939) and CMIN/DF ratio (3.25). Although $X^{2} / \mathrm{df}$ 
exceeds the cut-off of 3 - as suggested by Hair et al. (2014) - Sarantakos (2007) specifies that a $X^{2} / \mathrm{df}$ less than 5 is still acceptable.

As per Table 7, all paths in the structural model are significant and positive with standardised regression weights $(\beta)$ ranging between 0.155 and 0.651 . As is evident from Table 7 , customer satisfaction impacts positively on affective commitment $(\beta=0.155 ; p=$ value $=0.022)$ and trust $(\beta=0.500 ; p=$ value $<0.001)$. Customer value impacts positively on affective commitment $(\beta=0.213 ; p=$ value $=0.003)$ and trust $(\beta=0.399 ; p=$ value $<0.001)$, while trust impacts positively on affective commitment $(\beta=0.433 ; p=$ value $<0.001)$. In turn, affective commitment impacts positively on the four customer engagement dimensions: interaction $(\beta=0.435 ; p=$ value $<0.001)$, attention $(\beta=0.302 ; p=$ value $<0.001)$, absorption $(\beta=0.177 ; p=$ value $<0.001)$, and affection $(\beta=0.651 ; p=$ value $<0.001)$. In most instances, the $\mathrm{R}^{2}$ value obtained for each endogenous variables is greater than 0.1 , and were accordingly deemed adequate (Falk \& Miller, 1992). Specifically, trust obtained the highest $R^{2}$ value (0.718), followed by affective commitment (0.562), customer engagement affection (0.423), customer engagement interaction (0.189), customer engagement attention (0.091), and customer engagement absorption (0.031). Therefore, all replications and hypotheses could be supported.

Table 7. Replication and hypothesis testing results.

\begin{tabular}{|c|c|c|c|c|}
\hline Replications and hypothesis & $\boldsymbol{\beta}$ & S.E. & $p$-value & Result \\
\hline $\mathrm{R}_{1}: \mathrm{CS} \rightarrow \mathrm{AC}$ & 0.155 & 0.068 & $0.022 * * *$ & Supported \\
\hline $\mathrm{R}_{2}: \mathrm{CS} \rightarrow \mathrm{TR}$ & 0.500 & 0.58 & $0.001^{*}$ & Supported \\
\hline $\mathrm{R}_{3}: \mathrm{CV} \rightarrow \mathrm{AC}$ & 0.213 & 0.089 & $0.003 * *$ & Supported \\
\hline $\mathrm{R}_{4}: \mathrm{CV} \rightarrow \mathrm{TR}$ & 0.399 & 0.078 & $0.001 *$ & Supported \\
\hline $\mathrm{R}_{5}: \mathrm{TR} \rightarrow \mathrm{AC}$ & 0.433 & 0.070 & $0.001 *$ & Supported \\
\hline $\mathrm{H}_{1}: \mathrm{AC} \rightarrow \mathrm{CEINT}$ & 0.435 & 0.063 & $0.001 *$ & Supported \\
\hline $\mathrm{H}_{2}: \mathrm{AC} \rightarrow \mathrm{CEATT}$ & 0.302 & 0.052 & $0.001 *$ & Supported \\
\hline $\mathrm{H}_{3}: \mathrm{AC} \rightarrow \mathrm{CEABS}$ & 0.177 & 0.061 & $0.001 *$ & Supported \\
\hline $\mathrm{H}_{4 \text { (revised) }}: \mathrm{AC} \rightarrow$ AFFECTION & 0.651 & 0.060 & $0.001 *$ & Supported \\
\hline
\end{tabular}

Figure 2 below provides a summary of the research findings. 
Figure 2. Model reflecting replications and hypotheses results.

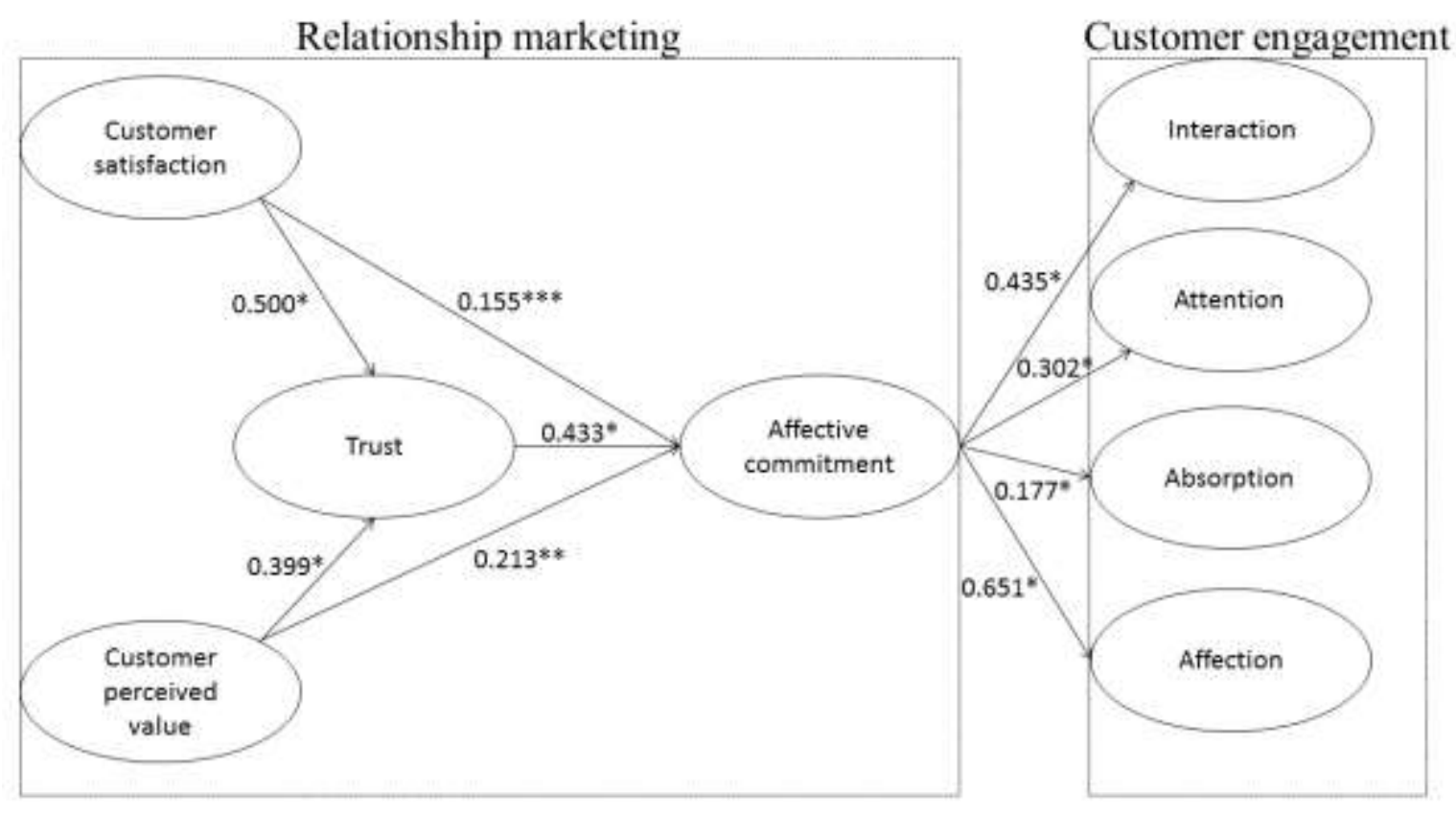

\section{Common method variance}

Finally, it should be noted that several techniques were employed in the ex-ante stage of the empirical investigation to control potential common method bias problems. As recommended by Podsakoff, MacKenzie, Lee, and Podsakoff (2003), the personal details of the respondents were not requested. The respondents were assured that participation in the study was completely voluntary and anonymous, and that individual responses would not be made known to the public. The measurement scales for the predictor and criterion variables were selected from different sources, and careful consideration was given in the formulation of the measurement items to avoid any double-barrelled statements. The questions were phrased in an uncomplicated manner and were easy to understand. In the ex-post stage of the empirical investigation, Harman's single factor test was first applied (Podsakoff et al., 2003). The findings revealed that the total variance explained by a single factor is 0.45 . While this result is high, it is still below $50 \%$, thereby indicating that the majority of the covariance among the constructs is not explained by a single latent factor. Second, a latent factor was added to the 
CFA model that was connected to all the observed items in the measurement model (Podsakoff et al., 2003). In some cases, the difference between the standardised regression weights of the re-specified measurement model and the initial measurement model that excluded the common latent factor were greater than 0.2. The subsequent structural equation model that retained the common latent factor still delivered a good model fit $(\mathrm{X} 2 / \mathrm{df}=3.209$, $\mathrm{GFI}=0.845, \mathrm{AGFI}=0.808, \mathrm{CFI}=0.944, \mathrm{TLI}=0.935, \mathrm{IFI}=0.944, \mathrm{NFI}=0.921, \mathrm{RFI}=0.908$, and RMSEA $=0.067$. Unfortunately, the standardised regression weights between the constructs measured did not remain significant $(p<0.05)$ in all instances. Following these findings, it is possible that some of the results in this article are inflated due to the common method effect. This is noted as a limitation in the study, and it is recommended that careful consideration be given in the selection of measurement scales when further examining the research findings in future studies.

\section{Discussion and conclusion}

\section{Theoretical implications}

The structural model confirms that customer engagement is an expansion of the relationship marketing domain (So et al., 2016, p. 9; Vivek et al., 2012, p. 128). Previous research acknowledges the antecedent effect of customer satisfaction, trust, perceived value and commitment on customer engagement (Hollebeek et al., 2016; Islam \& Rahman, 2016; Pansari \& Kumar, 2016; Van Doorn et al., 2010). Therefore, this study's findings further existing knowledge by offering more insight into the extent to which these relationship marketing factors are interrelated and may interact with one another prior to contributing to customer engagement behaviour. It appears that customer satisfaction and perceived value may impact trust and affective commitment $\left(\mathrm{R}_{1}-\mathrm{R}_{4}\right)$. Trust may also have an effect on affective commitment $\left(\mathrm{R}_{5}\right)$. Customers who are affectively committed may become engaged 
with the service firm in various ways $\left(\mathrm{H}_{1}-\mathrm{H}_{4 \text { (revised) }}\right)$. These findings are valuable as the interrelationship between key relationship quality factors and their effect on various dimensions of customer engagement have not been examined before. Subsequently, the research findings offer an initial understanding into the matter and set the scene for further research on this topic.

A further insight provided is that, considering the findings from the EFA, it is evident that the customer engagement dimensions, originally presented by So et al. (2014), may require adaptation in different service contexts. Specifically, it seems that in the short-term insurance industry, the measurement items related to customer engagement identification are not different from the items measuring customer engagement enthusiasm. Instead, they appear to be connected by a generic theme - 'affection' that involves feelings of 'liking and caring for someone or something' (Affection, 2017). In this study, affection concerns the feelings customers may develop towards their short-term insurance providers, which is shown in how they like and care for the provider. Furthermore, it seems reasonable to accept the findings of the EFA presented in this study. Compared to the other dimensions of customer engagement (interaction, attention and absorption), which are more cognitive in nature, the measurement items of the identification and enthusiasm constructs focus on the emotional feelings of the short-term insurance customers, which in this study are connected by the theme of feelings of affection, as denoted by views of liking and caring. The multidimensional view of customer engagement, comprising of a cognitive and affective component has also been acknowledged by other scholars in the field of customer engagement (Brodie et al., 2011; Vivek et al., 2012; Van Doorn et al., 2010).

Earlier studies have acknowledged affective commitment's ability to predict consumer behaviour (Curth et al., 2014, p. 148), noting that it is related to the emotional feelings customers have towards the organisation. Affective commitment 'develops through the degree 
of reciprocity or personal involvement a customer has with a company' (Gustafsson et al., 2005, p. 211), and, as stated in the literature review of this article, measures the feelings and emotional attachments customers may develop towards the service provider. This study's research findings appear to confirm the predictive power of affective commitment in prophesying consumer behaviour, as the impact of affective commitment on customer engagement has been verified. In addition, it then also appears that customers' emotional feelings may play an important role in their decision-making to reciprocate and display various forms of customer engagement behaviour.

\section{Managerial implications}

From a managerial perspective, it is first evident from the findings of the study that short-term insurers should focus on meeting and exceeding the expectations of customers. Meeting or exceeding their expectations will result in customer satisfaction with the service encounter, and will lead to overall customer satisfaction and trust (Hess \& Story, 2005, p. 315; Moreira \& Silva, 2015, p. 262). Customer satisfaction also has a positive and significant impact on affective commitment of customers to the short-term insurer (Hennig-Thurau, 2004, p. 465). Short-term insurers should carefully manage customer expectations and guard against overpromising. Due to the intangibility of the offer and the competitive nature of the industry, it is often easy for short-term insurers to fall into this trap of inflating customer expectations to acquire and retain business. Since customer satisfaction has a positive and significant impact on both trust and customers' affective commitment, an inability by the short-term insurer to meet customer expectations will negatively impact trust, affective commitment, and customers' level of engagement.

This study also found that providing customers with a sense of value, where they perceive that they are receiving more benefits than the cost they have to incur to obtain the benefits, will positively impact trust and affective commitment. Specifically, short-term 
insurers should ensure policy premiums are affordable and competitive; the service provided is flexible and includes additional benefits and financial assistance; and that customers have a good understanding of the exclusion sections of their insurance policies. Customers who receive value and are pleased with the service provided and also believe they have made a good purchase, will have a greater inclination to trust the short-term insurance provider and become affectively committed. Short-term insurance providers should also keep their promises to customers, put the customer's interest first and ensure the service provided is reliable - customers who trust the provider may also be more likely to be affectively committed and have feelings of emotional attachment towards the short-term insurance provider.

The study also established the positive impact of affective commitment on the dimensions of customer engagement (Islam \& Rahman, 2016, p. 2021). If the short-term insurer is able to increase customer satisfaction and a sense of perceived value among customers, it will be able to impact the extent to which customers engage with the short-term insurer. Short-term insurance providers who have developed quality relationships with their customers and provided value, may reap the benefits of engaged customers who are absorbed, relate to and are enthusiastic about the firm, and will engage in interaction activities beyond purchase.

\section{Limitations and directions for further research}

This study was conducted in the short-term insurance industry, using a non-probability sampling approach, and provided an initial understanding of the extent to which selected relationship marketing constructs interact with each other and contribute to customer engagement behaviour. A longitudinal research study with a cross-country analysis may verify the research findings on a larger scale and determine the degree to which they can be generalised for the larger population. Furthermore, in their systematic review of customer 
engagement, Islam and Rahman (2016) also noted several other antecedent factors which scholars believe may affect engagement. Consequently, it may be interesting to incorporate these variables into the current model and determine the extent to which they interact with the relationship marketing factors of this study to foster customer engagement. The impact of continuance and normative commitment on customer engagement also requires further investigation. It would be interesting to confirm the viability of the structural model in other service marketing contexts as well as the online retail environment, and to determine the extent to which the customer engagement affection dimension may be relevant in other service environments.

\section{References}

Affection. (2017). In Merriam-Webster. Retrieved from https://www.merriamwebster.com/dictionary/affection

Allen, N. J., \& Meyer, J. P. (1990). The measurement and antecedents of affective, continuance and normative commitment to the organization. Journal of Occupational and Organizational Psychology, 63(1), 1-18.

Aurier, P., \& De Lanauze, G. S. (2011). Impacts of instore manufacturer brand expression on perceived value, relationship quality and attitudinal loyalty. International Journal of Retail \& Distribution Management, 39(11), 810-835.

Babin, B. J., Darden, W. R., \& Griffin, M. (1994). Work and/or fun: Measuring hedonic and utilitarian shopping value. Journal of Consumer Research, 20(4), 644-656.

Bagozzi, R. P., Gopinath, M., \& Nyer, P. U. (1999). The role of emotions in marketing. Journal of the Academy of Marketing Science, 27(2), 184-206.

Bartlett, M. S. (1954). A note on the multiplying factors for various chi square approximations. Journal of Royal Statistical Society, 16, 296-298.

Berry, L. L. (1983). Relationship marketing. In L. L. Berry, G. L. Shostack \& G. D. Upah (Eds.), Emerging perspectives on services marketing (pp. 25-28). Chicago, IL: American Marketing Association.

Berry, L. L. (1995). Relationship marketing of services - growing interest, emerging perspectives. Journal of the Academy of Marketing Science, 23(4), 236-245.

Berry, L. L., \& Parasuraman, A. (1991). Marketing services. New York, NY: Free Press.

Bolton, R. (2011). Customer engagement: Opportunities and challenges for organizations. Journal of Service Research, 14(3), p. 272-274. doi:10.1177/1094670511414582

Bowden, J. (2009). Customer engagement: A framework for assessing customer-brand relationships: The case of the restaurant industry. Journal of Hospitality Marketing \& Management, 18(6), 574-596.

Bowden, J. L. H. (2011). Engaging the student as a customer: A relationship marketing approach. Marketing Education Review, 21(3), 211-228. 
Brodie, R. J., Hollebeek, L. D., Jurić, B., \& Ilić, A. (2011). Customer engagement: Conceptual domain, fundamental propositions, and implications for research. Journal of Service Research, 14(3), 252-271.

Brodie, R. J., Ilic, A., Juric, B., \& Hollebeek, L. (2013). Consumer engagement in a virtual brand community: An exploratory analysis. Journal of Business Research, 66(1), 105114.

Brodie, R. (2017). Enhancing theory development in the domain of relationship marketing: How to avoid the danger of getting stuck in the middle. Journal of Services Marketing, 31(1), 20-23.

Byrne, B. M. (1998). Structural equation modeling with LISREL, PRELIS and SIMPLIS: Basic concepts, applications and programming. Mahwah, NJ: Lawrence Erlbaum.

Calder, B. J., Phillips, L. W., \& Tybout, A. M. (1982). The concept of external validity. Journal of Consumer Research, 9(3), 240-244.

Cater, B., \& Zabkar, V. (2009). Antecedents and consequences of commitment in marketing research services: The client's perspective. Industrial Marketing Management, 38(7), 785-797.

Chen, Y. H., Wu, J. J., \& Chien, S. H. (2016). Impact of initial trust, involvement, and mood on trusting belief: Evidence from the financial industry in Taiwan. Journal of Service Theory and Practice, 26(1), 91-108.

Curth, S., Uhrich, S., \& Benkenstein, M. (2014). How commitment to fellow customers affects the customer-firm relationship and customer citizenship behavior. Journal of Services Marketing, 28(2), 147-158.

DeVellis, R. F. (2012). Scale development: Theory and applications (3rd ed.). Thousand Oaks, CA: Sage.

Diamantopoulos, A. and Siguaw, J.A. (2000). Introducing LISREL. London: Sage Publications

Doll, W. J., Xia, W., \& Torkzadeh, G. (1994). A confirmatory factor analysis of the end-user computing satisfaction instrument. MIS quarterly, 453-461.

Dootson, P., Beatson, A., \& Drennan, J. (2016). Financial institutions using social media - do consumers perceive value? International Journal of Bank Marketing, 34(1), 9-36.

Evanschitzky, H., Iyer, G. R., Plassmann, H., Niessing, J., \& Meffert, H. (2006). The relative strength of affective commitment in securing loyalty in service relationships. Journal of Business Research, 59(12), 1207-1213.

Falk, R. F., \& Miller, N. B. (1992). A primer for soft modeling. Akron, OH: University of Akron Press.

Financial Services Board. (2015). Annual report 2015. Retrieved from https://www.fsb.co.za/newslibrary/fsb\%20annual\%20report\%202015.pdf

Fornell, C., \& Larcker, D. F. (1981). Evaluating structural equation models with unobservable variables and measurement error. Journal of Marketing Research, 18(1), 39-50.

Fullerton, G. (2005). The impact of brand commitment on loyalty to retail service brands. Canadian Journal of Administrative Sciences/Revue Canadienne des Sciences de l'Administration, 22(2), 97-110.

Fullerton, G. (2014). The moderating effect of normative commitment on the service qualitycustomer retention relationship. European Journal of Marketing, 48(3/4), 657-673.

Grabner-Kräuter, S., \& Faullant, R. (2008). Consumer acceptance of internet banking: The influence of internet trust. International Journal of Bank Marketing, 26(7), 483-504.

Grönroos, C. (1994). From marketing mix to relationship marketing: Towards a paradigm shift in marketing. Management Decision, 32(2), 4-20.

Gummerus, J., Von Koskull, C., \& Kowalkowski, C. (2017). Guest editorial: Relationship marketing - past, present and future. Journal of Services Marketing, 31(1), 1-5. 
Gummesson, E. (2017). From relationship marketing to total relationship marketing and beyond. Journal of Services Marketing, 31(1), 16-19.

Gustafsson, A., Johnson, M. D., \& Roos, I. (2005). The effects of customer satisfaction, relationship commitment dimensions, and triggers on customer retention. Journal of Marketing, 69(4), 210-218.

Gutman, J. (1982). A means-end chain model based on consumer categorization processes. Journal of Marketing, 46(2), 60-72.

Hair, J. F., Black, W. C., Babin, B. J., \& Anderson, R. E. (2014). Multivariate data analysis (7th ed.). Harlow: Pearson.

Hajli, M. N. (2014). The role of social support on relationship quality and social commerce. Technological Forecasting and Social Change, 87, 17-27.

Hellier, P. K., Geursen, G. M., Carr, R. A., \& Rickard, J. A. (2003). Customer repurchase intention: A general structural equation model. European Journal of Marketing, $37(11 / 12), 1762-1800$.

Hennig-Thurau, T. (2004). Customer orientation of service employees: Its impact on customer satisfaction, commitment, and retention. International Journal of Service Industry Management, 15(5), 460-478.

Hess, J., \& Story, J. (2005). Trust-based commitment: Multidimensional consumer-brand relationships. Journal of Consumer Marketing, 22(6), 313-322.

Holbrook, M. B., \& Hirschman, E. C. (1982). The experiential aspects of consumption: Consumer fantasies, feelings, and fun. Journal of Consumer Research, 9(2), 132-140.

Hollebeek, L. (2011). Exploring customer brand engagement: Definition and themes. Journal of Strategic Marketing, 19(7), 555-573.

Hollebeek, L. D. (2012). The customer engagement/value interface: An exploratory investigation. Australasian Marketing Journal (AMJ), 21(1), 17-24.

Hollebeek, L. D., Srivastava, R. K., \& Chen, T. (2016). S-D logic-informed customer engagement: Integrative framework, revised fundamental propositions, and application to CRM. Journal of the Academy of Marketing Science, 1-25.

Ihantola, E.M., \& Kihn, L.A. (2011). Threats to validity and reliability in mixed methods accounting Research. Qualitative Research in Accounting \& Management, 8(1), 39-58.

Islam, J. U., \& Rahman, Z. (2016). The transpiring journey of customer engagement research in marketing: A systematic review of the past decade. Management Decision, 54(8), 2008-2034.

Johnson, M. D., Herrmann, A., \& Huber, F. (2006). The evolution of loyalty intentions. Journal of Marketing, 70(2), 122-132.

Johnson, M. S., Sivadas, E., \& Garbarino, E. (2008). Customer satisfaction, perceived risk and affective commitment: An investigation of directions of influence. Journal of Services Marketing, 22(5), 353-362.

Jones, M. A., Reynolds, K. E., Arnold, M. J., Gabler, C. B., Gillison, S. T., \& Landers, V. M. (2015). Exploring consumers' attitude towards relationship marketing. Journal of Services Marketing, 29(3), 188-199.

Kaiser, H. F. (1974). An index of factorial simplicity. Psychometrika, 39(1), 31-36.

Kandampully, J., Zhang, T., \& Bilgihan, A. (2015). Customer loyalty: A review and future directions with a special focus on the hospitality industry. International Journal of Contemporary Hospitality Management, 27(3), 379-414.

Karjaluoto, H., Jayawardhena, C., Leppäniemi, M., \& Pihlström, M. (2012). How value and trust influence loyalty in wireless telecommunications industry. Telecommunications Policy, 36(8), 636-649. 
Kassim, N., \& Abdullah, N. A. (2010). The effect of perceived service quality dimensions on customer satisfaction, trust, and loyalty in e-commerce settings: A cross cultural analysis. Asia Pacific Journal of Marketing and Logistics, 22(3), 351-371.

Kumar, V., \& Pansari, A. (2016). Competitive advantage through engagement. Journal of Marketing Research, 53(4), 497-514.

Landers, R. N., \& Behrend, T. S. (2015). An inconvenient truth: Arbitrary distinctions between organizational, Mechanical Turk, and other convenience samples. Industrial and Organizational Psychology, 8(2), 142-164.

Li, C. H., \& Chang, C. M. (2016). The influence of trust and perceived playfulness on the relationship commitment of hospitality online social network-moderating effects of gender. International Journal of Contemporary Hospitality Management, 28(5), 924944.

Liébana-Cabanillas, F., Muñoz-Leiva, F., \& Rejón-Guardia, F. (2013). The determinants of satisfaction with e-banking. Industrial Management \& Data Systems, 113(5), 750767.

Mackay, N. (2013). CRM initiatives of selected short-term insurance brokers (Unpublished doctoral thesis). North-West University, Potchefstroom, South Africa.

Mackay, N., Petzer, D. J., \& Mostert, P. G. (2014). Relational benefits and customer satisfaction - a South African short-term insurance industry perspective. Journal of Contemporary Management, 11(1), 302-323.

Mackay, N., Mostert, P. G., \& Petzer, D. J. (2015). The interrelationship between service quality, relational benefits, customer satisfaction and behavioural intentions in the South African short-term insurance industry. The Retail and Marketing Review, 11(1), 44-60.

Maharaj, Y. (2016). Will SA's short-term insurance industry prosper? Retrieved from http://www.insightsurvey.co.za/blog/will-sas-short-term-insurance-industry-prosper

Marinkovic,V, \& Obradovic, V. (2015) Customers' emotional reactions in the banking Industry. International Journal of Bank Marketing, 33(3), 243-260,

Menon, K., \& O'Connor, A. (2007). Building customers' affective commitment towards retail banks: The role of CRM in each 'moment of truth'. Journal of Financial Services Marketing, 12(2), 157-168.

Meyer, J. P., Stanley, D. J., Herscovitch, L., \& Topolnytsky, L. (2002). Affective, continuance, and normative commitment to the organization: A meta-analysis of antecedents, correlates, and consequences. Journal of Vocational Behavior, 61(1), 2052.

Monroe, K. B. (1979). Pricing: Making profitable decisions. New York, NY: McGraw-Hill.

Moorman, C., Deshpandé, R., \& Zaltman, G. (1993). Factors affecting trust in market research relationships. Journal of Marketing, 57(1), 81-101.

Morgan, R. M., \& Hunt, S. D. (1994). The commitment-trust theory of relationship marketing. Journal of Marketing, 58(3), 20-38.

Moreira, A. C., \& Silva, P. M. (2015). The trust-commitment challenge in service qualityloyalty relationships. International Journal of Health Care Quality Assurance, 28(3), 253-266.

Narteh, B. (2015). Perceived service quality and satisfaction of self-service technology: The case of automated teller machines. International Journal of Quality \& Reliability Management, 32(4), 361-380.

Oliver, R. L. (1981). What is customer satisfaction? The Wharton Magazine, 5(3), 36-41.

Oliver, R. L. (1997). Satisfaction: A behavioral perspective on the consumer. New York, NY: McGraw-Hill. 
Pallant, J. (2013). SPSS Survival manual. a step by step guide to data analysis using IBM SPSS. $5^{\text {th }}$ ed. Berkshire, England: McGraw-Hill.

Pansari, A., \& Kumar, V. (2016). Customer engagement: The construct, antecedents, and consequences. Journal of the Academy of Marketing Science, 45(3), 294-311.

Payne, A., \& Frow, P. (2017). Relationship marketing: Looking backwards towards the future. Journal of Services Marketing, 31(1), 11-15.

Podsakoff, P. M., MacKenzie, S. B., Lee, J. Y., \& Podsakoff, N. P. (2003). Common method biases in behavioral research: A critical review of the literature and recommended remedies. Journal of Applied Psychology, 88(5), 879-903.

Roig, J. C. F., Garcia, J. S., Tena, M. A. M., \& Monzonis, J. L. (2006). Customer perceived value in banking services. International Journal of Bank Marketing, 24(5), 266-283.

Sánchez-Fernández, R., \& Iniesta-Bonillo, M. Á. (2007). The concept of perceived value: A systematic review of the research. Marketing Theory, 7(4), 427-451.

Sarantakos, S. (2007). A toolkit for quantitative data analysis: Using SPSS. New York, NY: Palgrave MacMillan.

Saunders, M., \& Lewis, P. (2012). Doing research in business and management: An essential guide to planning your project. London: Pearson.

Scanzoni, J. (1979). Social exchange and behavioral interdependence. In R. L. Burgess \& T. L. Huston (Eds.), Social exchange in developing relationships (pp. 61-98). New York, NY: Academic Press.

Schlesinger, W., Cervera, A., \& Pérez-Cabañero, C. (2016). Sticking with your university: the importance of satisfaction, trust, image, and shared values. Studies in Higher Education, 1-17.

Segars, A., \& Grover, V. (1993). Re-examining perceived ease of use and usefulness: A confirmatory factor analysis. MIS Quarterly, 17(4), 517-525.

Sekhon, H., Ennew, C., Kharouf, H., \& Devlin, J. (2014). Trustworthiness and trust: Influences and implications. Journal of Marketing Management, 30(3-4), 409-430.

Selnes, F. (1998). Antecedents and consequences of trust and satisfaction in buyer-seller relationships. European Journal of Marketing, 32(3/4), 305-322.

Sheth, J. (2017). Revitalizing relationship marketing. Journal of Services Marketing, 31(1), 610 .

Shukla, P., Banerjee, M., \& Singh, J. (2016). Customer commitment to luxury brands: Antecedents and consequences. Journal of Business Research, 69(1), 323-331.

Silva, R., \& Correia, A. (2016). Places and tourists: Ties that reinforce behavioural intentions. Anatolia, 28(1), 14-30.

So, K. K. F., King, C., \& Sparks, B. (2014). Customer engagement with tourism brands: Scale development and validation. Journal of Hospitality \& Tourism Research, 38(3), 304329.

So, K. K. F., King, C., Sparks, B. A., \& Wang, Y. (2016). Enhancing customer relationships with retail service brands: The role of customer engagement. Journal of Service Management, 27(2), 170-193.

Tabachnick, B. G., \& Fidell, L. S. (2001). Using multivariate statistics (4th ed.). New York, NY: Harper \& Row.

Terblanche, C. (2016). South Africa's insurance industry under threat. FAnews. Retrieved from https://www.fanews.co.za/article/technology/41/general/1204/south-africa-sinsurance-industry-under-threat/20528

Van Doorn, J., Lemon, K. N., Mittal, V., Nass, S., Pick, D., Pirner, P., \& Verhoef, P. C. (2010). Customer engagement behavior: Theoretical foundations and research directions. Journal of Service Research, 13(3), 253-266. 
Van Tonder, E., Petzer, D. J., \& Van Zyl, K. (2017). A mediated model of relationship quality factors affecting behavioural intention at a luxury motor vehicle dealership. European Business Review, 29(1), 43-60.

Verhoef, P. C., Franses, P. H., \& Hoekstra, J. C. (2002). The effect of relational constructs on customer referrals and number of services purchased from a multiservice provider: Does age of relationship matter? Journal of the Academy of Marketing Science, 30(3), 202-216.

Vesel, P., \& Zabkar, V. (2010). Relationship quality evaluation in retailers' relationships with consumers. European Journal of Marketing, 44(9/10), 1334-1365.

Vivek, S. D., Beatty, S. E., \& Morgan, R. M. (2012). Customer engagement: Exploring customer relationships beyond purchase. Journal of Marketing Theory and Practice, 20(2), 122-146.

Wetzels, M., De Ruyter, K., \& Van Birgelen, M. (1998). Marketing service relationships: The role of commitment. Journal of Business \& Industrial Marketing, 13(4/5), 406-423.

Zeithaml, V. A. (1988). Consumer perceptions of price, quality, and value: A means-end model and synthesis of evidence. Journal of Marketing, 52(3), 2-22. 